STATE OF THE FIELD ESSAY

\title{
GENDER, VIOLENCE, AND SOCIAL JUSTICE IN ISLAM: MUSLIM FEMINIST SCHOLARS IN THE PUBLIC EYE
}

\author{
SHANNON DUNN \\ Assistant Professor, Gonzaga University
}

\begin{abstract}
BOOKS DISCUSSED
Sexual Ethics and Islam: Feminist Reflections on Qur'an, Hadith, and Jurisprudence, revised and expanded edition. By Kecia Ali. London: Oneworld Publications, 20r6. Pp. 320. \$I9.95 (paper). ISBN: 978-I7807438I3.

Domestic Violence and the Islamic Tradition. By Ayesha Chaudhry. New York: Oxford University Press, 2013. Pp. 288. \$34.95 (paper). ISBN: 978-0198766I93.

Sexual Violation in Islamic Law: Substance, Evidence, and Procedure. By Hina Azam. New York: Cambridge University Press, 2015. Pp. 286. \$95.00 (cloth). ISBN: 978I 107094246.
\end{abstract}

KEYWORDS: Islam, feminism, violence, sexuality, public scholarship, Islamophobia

Three recent books focused on law, gender, and Islam not only make important individual contributions to the field of law and religion, but together, in their attention to issues of gender, sex, violence, and law, signal an important development in both this field and the field of Islamic studies. This state of the field essay examines Kecia Ali's revised and expanded edition of Sexual Ethics and Islam, Ayesha Chaudhry's Domestic Violence and the Islamic Tradition, and Hina Azam's Sexual Violation in Islamic Law. Individually and collectively, these works shed light on the way that societies use gender as a fundamental tool of social organization and hierarchy. While Ali, Chaudhry, and Azam focus mainly on the classical Sunni Islamic tradition, their insight has wider methodological import for the study of law and religion. Further, they illuminate the intellectual diversity within the Islamic tradition, both in the past and in the present. In doing so, they draw attention to the process of how the intellectual tradition is retrieved and appropriated in contemporary contexts. Finally, their work is historical and descriptive as well as normative: this kind of scholarship challenges the distinction in the study of religion between these two categories. Ali, Chaudhry, and Azam each places her observations and arguments about classical Sunni Islamic texts and traditions in productive conversation with ethical and legal questions that Muslims face today.

To better situate these contributions, I incorporate elements of author interviews in discussing the politics of writing about Islam, gender, and violence. As Muslim scholars who offer constructive criticism of the classical Islamic tradition, Ali, Chaudhry, and Azam occupy a marginal space. One of the main reasons for this situation is the existence of a political dynamic in the West between 
those who question the credibility of Muslims as citizens and Muslims who worry that any criticism of the tradition will threaten the integrity of the Islamic tradition or lead to hateful acts against Muslims. Thus, although the Muslim feminist scholarship ${ }^{\mathrm{I}}$ that is the subject of this essay entails careful distinctions between historical periods and shows a rich texture of debate and dissent within the tradition, these features are often misunderstood or overlooked because of this dynamic.

Muslim scholars who write and speak critically about the tradition risk distortion of their arguments, and their political and religious allegiances might be questioned-not to mention their credibility as scholars. Consider the comment of one reader, a non-Muslim, to a New York Times article in which Kecia Ali's scholarship is used as a reference, invoked by the author of the article to talk about the history of sexuality and slavery in Islam: "I've read the postings of several Muslim apologists. I concede this does not represent the beliefs of a billion Muslims, but there is no arguing against the fact that like so many atrocities throughout history, an absurd and vile interpretation of a 'holy book' [the Qur'an] is at ground zero of this crime. How casually some intellectuals in this article 'explain' the behavior." 2

This comment illustrates both the need for good public scholarship on Islam and, at the same time, an argument that threatens to undercut it - one that reduces Muslims to members of a violent religion, incapable of reasoning. The scholar who provides historical nuance to the legal arguments around sex and slavery-and who has criticized many forms of violence in the tradition in her work -is accused of making excuses for it. This type of argument places Muslims in a double bind and treats them as an undifferentiated group. It is unsurprising, then, that some Muslims seek to defend their tradition by denying any connection between Islam and groups like the Islamic State in Iraq and Syria (ISIS), or by dismissing work by Muslim feminist scholars who are critical of the classical tradition's treatment of women and gender in part because it diminishes the possibility for argument and debate. In their scholarship, Ali, Chaudhry, and Azam address the importance of argument and dissent in the tradition, which provides a dynamism that both sustains and moves the tradition forward. They each examine types of arguments and the reasons that people give for them, and note the epistemological frameworks that govern thinking on gender, sex, and violence. While much of their work deals with historical phenomena, it is clear that they seek to reach a contemporary audience and to make a critical intervention in both Muslim and broader public discourse about Islam, gender, and violence.

\section{SEXUAL ETHICS IN ISLAM}

The revised and expanded edition of Ali's Sexual Ethics and Islam comes ten years after the first publication. This edition does not alter the original text, but instead provides a new commentary for each chapter, which is contained in a revised introduction, afterword, and codas. Moreover, the coda functions to update the reader on more recent scholarship related to the chapter and serves also as an invitation for further conversation. This editorial choice offers an effective way of

I I recognize that the term feminist has many connotations. Here, I use the idea of a "Muslim feminist" to signal a commitment to gender reform in the tradition through scholarship and activism. But I am not suggesting that all Muslim feminists have the same goals as a group or share the same assumptions and aims as Western liberal feminists, for example. The main reason for this choice is to keep the terminology fairly simple.

2 Phil, August I3, 2015 , comment on Rukmini Callimachi, "ISIS Enshrines a Theology of Rape,” New York Times, August I3, 20I 5, http://www.nytimes.com/20I 5/08/I4/world/middleeast/isis-enshrines-a-theology-of-rape.html? _r=o\#permid=I 5775786 . 
understanding shifts in Ali's thinking about her work on sex and gender in fiqh, classical Sunni jurisprudence.

In order to provide the necessary background to the commentary in the 2016 edition, it is appropriate to discuss the unchanged text from the 2006 edition. ${ }^{3}$ Ali argues that the study of classical texts is necessary for understanding how Muslims have constructed sexual ethics in the past and the present. For all of its flaws, "the Muslim intellectual, and especially, legal tradition provides significant ground for engagement on matters of ethics" (Ali, xxix). The question of what is lawful or ethical in Islam is not only the subject of intracommunal discourse, but, due to global political events involving Muslims, it has become an area of wider public curiosity and scrutiny.

Ali is forthright about the challenges faced by Muslims in a postcolonial and post-9/I I era of a global "war on terror." Broadly speaking, these challenges arise from historical Western political and military domination in parts of the Muslim world and the portrayal of Islam as a "backwards" and "uncivilized" tradition at odds with an "enlightened" Western liberalism. While this narrative does not adequately describe all interactions between Islam and the West, many Muslims have experienced a version of this political reality in relation to their religious and social identities. Ali explains how this experience can lead Muslim communities to adopt a defensive posture that seeks to preserve the integrity of the Islamic tradition. Thus, Muslims may be reluctant to engage in critical interpretations of Qur'an, hadith, and fiqh, and especially in relation to women's status, as well as sexual practices. The reasons for this reticence are complicated, but suffice it to say that there are issues of postcolonial masculinity, gendered hierarchies, and community identity that converge on this topic. As Ali writes in the afterword to the second edition, sex is such a prominent topic in contemporary Islamic discourse because "sex and gender norms connect to the legitimacy and authenticity of Islam writ large" (Ali, 202). Thus, the project of thinking about gender equality in relation to the classical tradition, which is also given attention in Ali's earlier book, Marriage and Slavery in Early Islam, ${ }^{4}$ is bound to be a contested one.

Ali argues for mutual consent and reciprocal desire as foundational principles for a sexual ethic and notes a serious discrepancy between these ideas and classical jurisprudential discourse. In the latter, lawful sexual relationships were framed by the conception of milk (ownership), due in no small part to the legality of slavery in the medieval period: "The basic understanding of marriage as a relationship of ownership or control is predicated on an analogy to slavery at a fundamental level, and the discussion of wives and concubines together strengthens the conceptual relationship" (Ali, xxxiv). Although slavery has been outlawed in the Islamic world, the conceptual framework of milk still influences Muslim thinking about marriage. Given the "great psychic distance" that separates contemporary Muslims from the historical context in which legal doctrines were originally formulated, Ali maintains the importance of revisiting classical texts that deal with sexual rights and duties and of exploring new ways of interpreting them.

The chapters of Sexual Ethics and Islam examine various practices according to the classical tradition-dower; male-initiated divorce; concubinage and slavery; same-sex relationships; female circumcision; child marriage-and the conceptual interconnectedness that ties each of them back to practices of ownership. For example, Ali observes that a husband's power of divorce is related to his exclusive control over marriage, "just as a master's power of manumission resulted from his ownership of a slave" (Ali, 40). Thus, she urges Muslims to adopt a more comprehensive

3 I have chosen this strategy in part because I already had familiarity with the 2006 edition. Therefore, my experience of reading the second edition will be different from that of a person who encounters Ali's Sexual Ethics and Islam for the first time via this second edition. (All citations are from the 2016 edition.)

4 Kecia Ali, Marriage and Slavery in Early Islam (Cambridge, MA: Harvard University Press, 20Io). 
approach to the reform of Islamic laws and traditions involving marriage and divorce, which would create better opportunities for gender equality.

Ali argues that contemporary Muslim scholars and other authority figures within the tradition ought not to evade difficult questions about gender, sex, and slavery. She thinks that despite the criticisms posed by Islamophobic voices that Muslims must address the difficult questions of the tradition. On the one hand, it is understandable that scholars in the contemporary polemical context (in which Muslims have been defined as "others") would attempt to gloss over such texts or offer defensive interpretations of them. On the other hand, scholars must acknowledge key historical differences between the formative period of Islam and the present, such as the abolition of legal slavery. The premodern interpreter, for example, would have taken for granted the social inequality of women.

The major methodological issue that Ali identifies is how to differentiate the timeless or unchanging aspects of the tradition and those that are subject to change with time. This means approaching revelation in such a way that "allows one to interpret scripture without being bound by the assumptions of previous exegetes who accepted male superiority and other social hierarchies, including slavery, without question" (Ali, 65). This is not a simple process, and doing it well requires that Muslims grasp their specific historical-social situation and the dynamism that exists between inherited tradition and lived experience. For example, Muslims in North America in the contemporary period will be shaped by their particular experiences as citizens of a secular state, informed by the ideal of equal protection before the law. This ideal conflicts with the very notion of legal slavery as it was understood in the late antique and medieval worldview of Islam. Through a study of classical arguments, Muslims today might learn how jurists justified slavery in that context, without agreeing that it was an acceptable practice. As the historical circumstances of Muslims change, the governing assumptions about the world and the way it works are bound to change also. Applied to questions of gender equality, Ali maintains, there are no longer justifiable reasons for Muslims to accept gendered hierarchies.

In the preface to the expanded edition of Sexual Ethics and Islam, Ali explains that she is more attentive to how the problems of racism, classism, and imperialism "shape the production of ideas as well as lived realities" (Ali, xvii). Political events like the Arab Spring and its repression, and the rise of the so-called Islamic State and the ongoing U.S. military response to it, continue to influence the landscape of Islamic interpretation and the contest over authority. Ali explains her interest in examining the structural dimensions of injustice, noting continuities between U.S. state-sponsored violence against African Americans and the violence of the war on terror. Moreover, in contexts of violent upheaval, women often suffer disproportionately from rape, sexual assault, and domestic violence. Thus, she argues, there remains an urgent need to continue the study of sex, gender, and Islam, and to continue the conversation with newer voices in the field.

The codas to each chapter contain brief reflections on some of the following topics: family law in Muslim-majority and Muslim-minority societies; polygyny; the Islamic State's defense of slavery on Islamic grounds; the Western media's distortion of hudud laws (specifically, those that deal with punishment for adultery and related crimes) and shari ${ }^{i}$ more generally; same-sex relationships and gender identity; and Western aversion to female genital cutting. One theme that runs across all chapters and codas is the Western media's selective and frequently distorted readings of the Islamic tradition. These selective readings - which are often unoriginal reiterations of earlier colonial tropes - affect not only popular conceptions of Muslims but also influence policy. News outlets often highlight examples of Muslims in war that appear to reveal their "true" barbarity and backwardness. Thus, while it is imperative that Muslim scholars and others continue to think critically 
about classical fiqh in relation to sex and gender, there is an intersectional element of injustice that also requires work.

In order to be meaningful to contemporary Muslims and advance justice, ongoing interpretation of classical texts must incorporate a structural analysis of power and answer to human experience. Ali observes in the afterword to the expanded edition that while the original edition focused on authority and consent, the new material deals more with power and experience. Power consists not only of the power to interpret the tradition, but the larger field of political power (and the violence that often accompanies state power) that influences human experience, both engendering and constraining agency. Political arrangements in traditionally Muslim lands, particularly in the Arab world, ought to be taken into account when understanding how Muslims interpret the Islamic tradition and power within it. These arrangements may be understood as broadly encompassing dictatorships to occupations to military interventions by foreign countries. Experience both includes the sheer cultural diversity of expressions of Islam and also constitutes an important source for ethical decision-making.

In sum, in her revisions and expansions to Sexual Ethics and Islam, Ali continues to emphasize the need for close readings of classical texts, in which Muslims take interpretive responsibility for how they understand and apply such texts in personal and communal life. Ali argues that being able to justify one's choices about which norms to endorse, or reject, is an important feature of subjectivity. And yet, the new material in this edition takes into consideration that the larger social and political arrangements and pressures, which are outside of a person's immediate control, make the act of interpretive responsibility a complex endeavor.

The concept of interpretive responsibility emerges as a consistent theme in all three books under review. At a basic level, it entails that Muslims do not merely repeat conventional wisdom about what "Islam" says, but that they engage in critical reflection on sacred texts and traditions. Responsibility thus involves an awareness of oneself as an interpreter, located in a particular historical and political moment. But Ali, Chaudhry, and Azam also recognize that even though interpretive responsibility is a kind of ethical imperative, sometimes political and social crises threaten the ability of subjects to think of themselves and others in such ways. In all three books, the reader is reminded of the necessity of interpretive responsibility, but also its fragility.

\section{DOMESTIC VIOLENCE IN ISLAM}

Chaudhry's Domestic Violence and the Islamic Tradition also deals with the question of interpretive responsibility, but in this case with reference to a specific verse of the Qur'an. Chaudhry documents in painstaking detail the different exegetical and legal arguments related to Qur'an 4:34, a verse that allows for Muslim men to beat their wives. One of the strengths of the book is Chaudhry's ability to show a diversity of Muslim arguments related to the interpretation of 4:34. By situating this text within the larger Qur'anic corpus, as well as various pre- and postcolonial commentaries, Chaudhry argues that the question of whether a discrete action (wife beating) is permissible depends, in significant part, upon one's cosmology. The precolonial cosmology is marked by a gendered hierarchy in which men are seen to be closer to God than are women. This particular cosmology offered a basis for understanding social relationships and ethical practices. Verse 4:34 reveals this ideal of a divinely ordered universe. Chaudhry notes, "When wives disobeyed their husbands or demonstrated any form of recalcitrance, they threatened an entire cosmological order" (Chaudhry, 55). By contrast, the competing postcolonial idealized cosmology is grounded in a concept of gender egalitarianism and acknowledges the equal worth of women. In 
this postcolonial cosmology, men no longer mediate women's relationships with God. Such a cosmology thus threatens the patriarchal underpinnings of the precolonial ideal.

Chaudhry identifies different factors that have facilitated a changed cosmology in the postcolonial period, notably a difference in the production of religious knowledge, including the blurring of traditional genres, the use of non-Arabic Islamic sources, and the expansion of authoritative Muslim voices beyond the scholarly elite, including the participation of Muslim women (Chaudhry, I37-38). She reminds the reader that whether or not the modern Muslim is explicitly aware, she is always juggling and choosing between competing cosmologies. People who are simultaneously participants in modern societies and adherents to faith traditions that originated in premodern history will often struggle in an attempt to reconcile incompatible cosmologies.

In classifying the various responses to these competing cosmologies, and the interpretive strategies to which they have given rise, Chaudhry describes four different groups: traditionalists, neotraditionalists, progressives, and reformists. The first two groups adopt a patriarchal cosmology, while the latter two follow a gender-egalitarian cosmology. Of these four groups, the first three view the inherited Islamic tradition as an obstacle to be reconciled with postcolonial Islamic sensibilities about gender. Descriptively, this makes sense-particularly for neo-traditionalists and progressives who engage in "intricate hermeneutical acrobatics" to balance these opposing cosmologies (Chaudhry, I40).

While certain social factors may explain the rise of a gender-egalitarian cosmology, traditionalist and neo-traditionalist Muslims have not been persuaded by it. One reason for this, Chaudhry argues, is that "In spurning the pre-colonial, patriarchal cosmology, these scholars must discard the Islamic tradition; that is, they must reject all pre-colonial understandings of the right of husbands to hit their wives as outlined in $4: 34$ " ( $\left.\mathrm{I}_{3} 8\right)$. Although she sympathizes to a limited extent with the problem of authority presented by the gender-egalitarian paradigm, Chaudhry criticizes most trenchantly traditionalist and neo-traditionalist reasoning: "Holding onto a patriarchal idealized cosmology in the post-colonial period requires scholars to be somewhat divorced from their own social and historical reality, where scientific and social advances have demonstrated that men are not physically and intellectually superior to women" (Chaudhry, I40). Modern Muslims who argue for gender complementarity - the concept that men and women have unique and well-defined social roles based on their God-given biological differences - are actually reiterating a version of the pre-colonial patriarchal gendered cosmology, but with a different line of reasoning.

Progressives also face the gender-egalitarian dilemma: they reject the patriarchal cosmology underlying verses like 4:34, but they still want to be persuasive and authoritative in Muslim communities and therefore must maintain continuity with the historical tradition. One way to do this is to distinguish between the Qur'an as the divine word of God and fallible human interpretation; progressive interpreters may offer new and innovative meanings of key terms. In short, they look to follow precedent within the tradition (Chaudhry, I74). One of their methods is to combine traditionalist scholarship with Western academic training-and this leaves some other more traditionalist and neo-traditionalist scholars suspicious of their work.

Reformist scholars and activists explicitly reject the precolonial patriarchal Islamic tradition and emphasize instead the need for critical interpretation of and engagement with texts (Chaudhry, I 86). They recognize that this requires separating themselves from an imagined, pristine Islamic tradition. These scholars have developed strategies for addressing the crisis of authority that often follows as a consequence of such separation: engaging in innovative readings of the Qur'an; justifying their departure from the tradition on ethical and moral grounds; and embracing the methodology rather than the content of the Islamic tradition (Chaudhry, I87). When interpreting Qur'an 4:34, 
for example, they may opt for nonviolent interpretations of the text. Chaudhry explains that reformists assert their subjective experience as authoritative, sometimes by insisting on a complete break between precolonial ideas of gender and contemporary ideas of gender (I94). For egalitarian readings of 4:34 to be authoritative, Muslim scholars must allow the Qur'an to be a performative text, "so that Muslims can struggle with and determine its contemporary meanings" (Chaudhry, 222). In treating the Qur'an as a performative text, reformist Muslims move away from the Islamic tradition as an essential entity and envision it more as a living tradition. Innovative hermeneutical strategies are required, as is recognition that people make choices that influence their interpretations.

Like Ali, Chaudhry is conscious of the Western political narrative that marginalizes Muslim voices and portrays Islam as a "backwards" tradition. She is also acutely aware of Muslim backlash and apologetics, and how this dual reality affects the reception of her work. In the introduction, she argues that such concerns should not prevent Muslim scholars from examining their tradition critically. She argues that catering to "bigots" will only produce a "sterile, sanitized, monotonous, and dehumanized version of Islam" (Chaudhry, I9). Chaudhry labels this the "public relations" version of Islam, as it showcases only the most positive aspects of Islam. In order for Muslims as a community to more fully embrace the gender-egalitarian vision of Islam, they must confront difficult texts and interpretations and provide better ones.

\section{SEXUAL VIOLENCE IN ISLAM}

Azam's Sexual Violation in Islamic Law examines the category of sexual violation in the Sunni jurisprudential tradition, and in particular within the Hanafi and Maliki legal schools. As do Ali and Chaudhry, Azam compares and analyzes scholarly discourses from a much earlier era in order to address the problem of sexual violence in the present. Azam observes, "Legal institutions in many majority-Muslim states function to promote violence against women in systematic ways" (Azam, I). She presents several case studies that demonstrate the association of this legally sanctioned violence with modern state implementations of shari $a$.

Azam explains that she sets out to provide "a unitary object of study out of elements that are not always explicitly connected in the texts" (Azam, I7). She chooses this method in order to present to the modern reader an understanding of how a concept of rape was constructed in classical jurisprudence and to relate it to the broader culture of the pre-Islamic Near East. The main texts of the study are the Qur'an and athar, the legal tradition literature. Azam's goal is to establish a theoretical and narrative account of how "Islamic ethico-legal discourse came to construct categories that we would designate as rape" (Azam, I 7). For example, the concept of rape in United States criminal law today is understood as a violation of another person's autonomy and sovereignty; however, this definition would not translate in the context of classical Sunni jurisprudence. The idea that a woman exists as a legally and socially autonomous being is a social construct that has developed over time in many contexts, both Islamic and non-Islamic, although it has roots in premodern legal discourses.

Azam compares the conceptualization of sex, gender, and violence in late antique civilizations and early Islam. She observes two general patterns-one proprietary, the other theocentric-that emerge from these civilizations, and each appears to be quite influential on the development of concepts related to sexual violation and women in the madhhab, Islamic legal schools. In the proprietary model, the punishment for sexual violation of a woman-married or unmarried-requires some type of monetary compensation to her husband or father, or in some cases the woman herself. 
Although variations existed between ancient Roman, Israelite, and Hellenistic cultures, in the proprietary model, the primary concerns are the father's or husband's loss of property and management of the reproductive capacity of the woman. For Romans, who sometimes practiced bride capture, the social class of the violated woman determined how punishment was meted out. Sexual purity, rather than a woman's volition, figured as a central consideration in the logic of the justice system (Azam, 50).

Pre-Islamic Arabians conceptualized sexuality in ways that would change after the advent of Islam. They held proprietary views of sexuality, and the practice of bride capture was also common. Before Islam, the concept of zina - a term that is associated with adultery in a later Islamic contextwas associated with polyandry and harlotry. Azam notes that zina did not carry the negative valence that later came to be associated with it in Islamic scriptural and juristic traditions.

In the theocentric model, by contrast, rape or sexual violation is interpreted as an act against God and a disruption of the divine order. Women are viewed as individual ethico-legal subjects, but the theocentric emphasis also positions God as the arbiter of virtue, and as the "person" wronged in an act that is sexually illicit. In lieu of monetary compensation for sexual violation, corporal punishments are the method of correction in the form of hadd punishments. Following a theocentric logic meant that jurists viewed unlawful sex not strictly in terms of property theft, but instead as a transgression of the boundaries of God, or budud Allab (hence the term "hadd" punishments). The idea is that since God commands virtue, "moral transgressions could only be remedied corporally, through a disciplining of the transgressor himself, in body" (Azam, 37). Islamic theocentrism stipulated individual human accountability before God, and it was used by jurists to distinguish voluntary versus coerced sexual acts. In this framework, zina moves from being a rather neutral concept to become a term involving moralistic notions of piety and sinfulness (Azam, 58).

This theocentric orientation was first expressed in Mosaic law and then in early Christian teachings. The church father Augustine also emphasized a theocentric approach in his emphasis on chastity as an internal state, ${ }^{5}$ which gradually came to replace ancient ideas about sexual violation as theft (Azam, 52). Azam postulates that the Qur'an and attendant religious discourses "altered Arabian approaches to female sexuality and sexual violation significantly, introducing a pattern that was much more in line with surrounding religio-legal patterns” (Azam, 59).

Azam observes that the theocentric and proprietary approaches worked well together in Islamic juristic constructions of licit sex, but conflicted in the area of illicit sex (88). Several chapters are organized around the tension between these two distinct approaches. One of the major points of contrast between the Hanafi and Maliki schools' treatment of sexual violation pertains to the former's emphasis on theocentrism and the latter's emphasis on property. Interestingly, Azam argues that a proprietary approach adopted by the Maliki school was actually more equitable to women as it treated the women in question as property owners of a kind (owners of their own bodies). In focusing on the problem of sexual coercion of free women, Azam makes the point that free women were in essence the synthesis of person/thing, or property/proprietor. (This idea builds on the classical framework of milk, also described by Ali.) The idea of the "free" woman constituted a contradiction in the classical Sunni legal paradigm - as it did in other ancient civilizations in which women could not be property owners, or had limited rights in marriage. Hence, there was much ambiguity in this category, as opposed to a female slave for whom the paradigm of ownership

5 See his discussion of the rape of the Sabine women in Augustine, City of God, Book 2. 
was clearly legally demarcated. Her argument is that of the two schools, the Maliki emphasis on sexuality as a commodity led to a more just outcome for victims of sexual violence.

Azam maintains that Maliki jurists recognized the legal dilemma of the victim of sexual violation who was technically a free woman but did not have all the legal rights of a man. Marriage, according to the Malikis, involved monetary exchange for sexual benefits. Although it may seem counterintuitive, this arrangement also served to establish a type of personhood for a free woman: "For medieval Muslim jurists, to be free meant to be a proprietor, that is, a property owner. The free person, even if he or she owned nothing, could claim ownership of self" (Azam, I I9). Maliki jurists categorized rape "not only as coercive zina but also as an act of sexual usurpation, or ightisab" (Azam, 237). Furthermore, the Malikis adopted a doctrine of the equal value of human and divine rights, meaning that the crime of rape was analyzed according to both (Azam, I42).

The Hanafis, by contrast, consistently treated rape as a matter of sexual transgression and moral volition and favored a divine-rights model over a human-rights model (Azam, I 54). Azam shows that in comparison with the Malikis, the Hanafis had no parallel concept of rape. She argues that the former group's dual-rights theory of rape was more equitable than the latter's focus on the rights of God (buquq Allah). This is because the Maliki insistence on monetary compensation for sexual violation actually constituted recognition of women's personhood. By focusing more exclusively on the rights of God, the Hanafis were less able to recognize the human rights of women. This significant difference of positions within the classical period shows not only inherent diversity in the Islamic tradition of fiqh, but also might be utilized in thinking about the appropriation of fiqh in the current context.

Azam concludes the book by focusing on the relevance of her study for contemporary Islamic legal systems. A major issue plaguing contemporary applications of Islamic law on matters of sex is that "there exist substantial degrees of misunderstanding about and misapplication of classical Islamic rape theory ... [that] result in overwhelming discriminatory outcomes for victims of sexual assault in Muslim states that seek to implement sharia-based laws” (Azam, 246). More precise analysis is needed for Muslims to critique relevant laws and to be able to distinguish classical jurisprudence from the legal arguments that masquerade as such.

\section{MUSLIM FEMINIST SCHOLARS AND THE CHALLENGE OF PUBLIC SCHOLARSHIP}

In order to help readers better appreciate the nature of this Muslim feminist scholarship, but also to shed light on the unique challenges of its production, I thought it would be useful to interview each of the three authors. In what follows, I highlight elements of my conversations with Ali, Chaudhry, and Azam and attend to the interplay between their scholarship in religion and law and their experiences navigating this work as North American Muslim women in politically tenuous times. In these conversations, I was struck, above all, by how each scholar, in addition to advancing an erudite scholarly discourse on figh or tafsir (Quranic exegesis) - has intervened in critical public discourse about religion and law, particularly as it pertains to questions of otherness, Muslim identity, and gender.

I also noted how each scholar situated her work as part of a larger whole. Each discussed experiences that conveyed a strong connection with a community of Muslim scholars, and in particular Muslim feminist thinkers. In their careful scholarship on classical Islamic texts and gender, each has benefitted from and built upon the work of earlier scholars of gender and Islam, including such leading figures as Fatima Mernissi, Leila Ahmed, Asma Barlas, Ziba Mir Hosseini, and Amina Wadud. In viewing themselves as inheritors of this type of critical feminist scholarship, they 
took care to highlight the work of newer scholars in the field, such as Aysha Hidayatullah, Jerusha Lamptey, and others. They also mentioned male Muslim scholars writing about gender, who were supportive of such work, including scholars such as Ebrahim Moosa, Khaled Abou El Fadl, Anver Emon, Farid Esack, and Mohammad Fadel. For Chaudhry and Ali in particular, the work of Jewish and Christian feminist scholars-like Judith Plaskow, Rachel Adler, Phyllis Trible, and Serene Jones-came up as important influences.

The creation of a trusted community of scholars around women, gender, and Islam over several decades has enabled the production of rigorous work in the field. Such a community may help these scholars face the unique challenges of doing their work in a political climate that can be quite hostile to Muslims - particularly Muslim women. Azam recalled a formative experience in graduate school, when she took a class in women's and gender studies. After she spoke up during a discussion about women's rights and religion, another student turned to her and said something to the effect of, "What in the world would you have to say about women's rights and Islam, when there is no such thing?" Azam said that important changes have taken place since that timemore Muslims entering the field of Islamic studies and producing significant research on Islamic law. ${ }^{6}$

This point brings us to the first of the several contributions of these three scholars to the field of law and religion: a better understanding that the construction of otherness occurs in all societies, whether ancient, medieval, or modern-or Muslim, Christian, Jewish, or secular, for that matter. Azam's story highlights the intersection of Islamic and female "otherness" in the contemporary context. All three scholars focus on gender in classical Islamic texts-gender being one major way of classifying and dealing with an "other." Thinking about how this insight applies more broadly to the study of law and religion, scholars might be more conscious of how gender is an organizational tool that frames thinking about personhood, property, and conceptions of rights. Chaudhry, Ali, and Azam help us to understand that gender is hardly peripheral to the maintenance of social orders and religious worldviews. Moreover, they emphasize that different views about gender within Muslim communities have led to substantial disagreement between legal scholars and laypersons.

When we add the study of violence to sex and gender, we can discern that violence against others is itself something managed by the law. Violence is carefully justified in legal traditions and ethical arguments dealing with domestic violence, rape, and female genital cutting, for example. Although these three books deal primarily with late antique and medieval treatments of gender and violence, they have relevance for the current context. Collectively, the books encourage the reader to engage in reflection about socially sanctioned forms of violence (whether lawful or tacit) and the social hierarchies and contexts that permit, and even naturalize, violence against "others."

Inevitably, 9/I I and the ongoing war on terror have influenced both academic and public discourse on Islam. The rise of the Islamic State and Western media coverage of it have exacerbated public anxiety about Islam in Western countries. In an August 2015 piece for the Huffington Post, Ali addressed the Islamic State's use of sex slavery in response to an article in the New York Times that had cited her work.7 In the Huffington Post article, she stated that while slave-holding was permissible in the late antique world of early Islam, there are good reasons to understand ISIS's arguments about slavery and sexuality as distortions of the tradition today. Ali denounced the

6 Hina Azam, interview with the author, July 2I, 2016.

7 Kecia Ali, "The Truth about Islam and Sex Slavery History Is More Complicated than You Think,” Huffington Post, August I9, 20I 5, http://www.huffingtonpost.com/kecia-ali/islam-sex-slavery_b_8004824.html. Ali wrote the article in response to Callimachi, "ISIS Enshrines a Theology of Rape." 
media for its uncritical acceptance of claims that ISIS's arguments represent "authentic" Islam, observing that such accounts too easily comport with a historical trope of Muslim barbarity. Ali argues that it is also important for Americans to assume responsibility for how U.S. military actions in Iraq and elsewhere in the Middle East have contributed to the political crisis that spawned ISIS. Shortly after its publication, U.S. anti-Muslim bloggers Robert Spencer and Pamela Geller shared the Huffington Post piece and publicly criticized it. Ali began to receive hate messages through e-mail and Twitter, many of which were extremely misogynistic in tone. Some messages suggested that Ali attempted to justify sexual slavery in Islam, or that she herself should become a sex slave.

In reflecting on publishing in this type of social and political context, Ali insists: "The existence of well-funded and frightening Islamophobic currents means that there is a real need to insist on the basic humanity of Muslims. It also means that any work that is critical of patriarchal and misogynist elements in the tradition-no matter how carefully contextualized and historicized-can be taken up and weaponized by those who wish to treat Muslims as less-than-human." 8 The description of "weaponizing" elements of the tradition is powerful, as we have witnessed the development of a very reactive public sphere, especially through the use of online media, in which many people are not interested in entertaining nuanced perspectives. (This phenomenon has also coincided with both calls for public scholarship and attacks on higher education.) When combined with anti-Muslim sentiment, it is not difficult to see how the meticulous work of scholars like Ali, Azam, and Chaudhry could be oversimplified and used for politically malicious ends.

Making a weapon of tradition also pertains in a rather literal way to a story that Chaudhry related to me, from her time as a graduate student. Some Muslims fear that any scholarship critical of the Islamic tradition will enflame anti-Muslim prejudice in communities that are satisfied with a one-dimensional ideological view of Islam. When Chaudhry was working on her dissertation on domestic violence and Islam, a Muslim professor at an Ivy League school invited her over for dinner and told her, "I hate what you are working on. Your book is going to be used to justify the bombing of Muslims." 9 The professor may have been referring to the ways that colonial powers have justified military intervention against Muslim countries, by arguing that they were "saving" brown women from brown men. ${ }^{10}$ For some Muslims, such public critique of the tradition is equivalent to airing the community's dirty laundry in front of people who would seize any opportunity, small or large, to undercut Muslims.

Chaudhry is aware of the particular pressures she faces as a North American Muslim woman writing about gender and Islam, but these pressures also seem to energize her in productive ways. Although painful at the time, this interaction with the professor inspired Chaudhry's criticism of the "public relations" view of Islam in her book, but it also reinforced her desire to make a careful, textually supported argument in her book. (She referred to herself at one point in the interview as the "queen of footnotes.") She said that while understandable, the "community under siege" mentality prevents Muslims from thriving and taking care of one another. ${ }^{\text {II }}$

In their research on sexual ethics and violence in Islam, Ali, Chaudhry, and Azam are helping to develop the fields of Islamic studies and Islamic jurisprudence. By engaging in constructive critique of tafsir or fiqh on matters of gender, these scholars and others like them contribute to a socioreligious vision of reform along more gender egalitarian lines. They also preserve a critical role

8 Kecia Ali, interview with the author, June 3, 2016.

9 Ayesha Chaudhry, interview with the author, June 27, 2016.

Io Leila Ahmed's description of this phenomenon in the British colonial context is helpful. See Leila Ahmed, Women, Gender, and Islam: Historical Roots of a Modern Debate (New Haven: Yale University Press, I992). 
for debate and dissent within the larger tradition, and fight a one-sided portrayal of the Islamic intellectual tradition-a portrayal that is taken up by both defensive insiders and ignorant and/ or menacing outsiders. Azam and Ali each attend to the diversity within the classical fiqh, noting similarities between legal schools as well as critical differences. Chaudhry identifies four paradigms in contemporary Muslim interpretations of the Qur'an. These methods of analysis provide strong evidence of a complex classical tradition, as well as ongoing diversity within the tradition in the current context.

This concern for diversity and dynamism within the tradition also surfaced in the interviews. Azam explained, 'It's easy to say, 'Islamic law is bad for women.' But that isn't always the case. There is a spectrum within classical jurisprudence, and there are those who did what they could to locate rights for women within the tradition." ${ }^{\mathrm{I} 2}$ Although classical jurists may have operated under a different paradigm of gender and sexuality, some of them had progressive ideas about women's religious rights for their time. This kind of diversity is important for thinking about how traditions are retrieved, and what kinds of possibilities there exist for creative adaptation of tradition in the present.

Thinking more broadly, Ali suggested that attention to diversity within a tradition is related to the larger society's ability to foster tolerance and opportunities for common understanding. "We need to create room in our societies for difference and dissent ... [without such room] Muslims are much more likely to draw the bounds of orthodox belief and acceptable conduct very narrowly." "I3 If Muslims live in an intolerant society-whether it is Muslim-majority or not-they are not as likely to be able to do the work of constructive criticism, whether it is around gender, sex, or another topic that generates debate. This observation also affirms the necessity of smaller communities, like the community of Muslim feminist scholars, which can engage in the kind of supportive, and yet critical, discourse that allows for constructive research.

This brings us to the question of the social institutions and spaces that can contribute to the development of a public that can tolerate dissent. While each of these scholars was careful not to romanticize the academy (and the place of female scholars within it), each argued that it has offered Muslim women scholars the space to not only become leaders in their respective fields, but to influence the wider community of Muslims. Chaudhry explained that association with the academy has conferred upon Muslim feminists an authority that they may not have in the mosque or madrasa. She described the academy as a "precious space" in which her right to be critical is protected. ${ }^{\mathrm{I}}$ Azam reiterated this idea: "A lot of Muslim women are achieving status and authority through their academic work, and are beginning to be recognized as a result in other institutions in the Muslim community." "5 Ali also agreed that the academy has functioned as an important space for male and female Muslim scholars, but also noted that Muslim religious institutions today are diverse and undergoing change. She mentioned the participation of women at the neo-traditionalist Islamic liberal arts institution, Zaytuna College, and the prominent role that Muslim scholar Ingrid Mattson has played in a number of national Muslim organizations. ${ }^{\mathrm{I} 6}$

There is little question that the academic platform has provided an opportunity for these scholars to reach diverse public audiences, from public and private university students to groups of lay Muslims. Ali was surprised when Sexual Ethics and Islam, intended originally for Muslim feminists inside and outside of the academy, began to be used widely in college classrooms. Part of her

I2 Azam, interview.

I 3 Ali, interview.

I4 Chaudhry, interview.

I 5 Azam, interview.

I6 Ali, interview. 
rationale for writing an updated version was that if the book was some university students' only exposure to Islam, she wanted to incorporate references to important new work in the field, offering a "roadmap" of sorts to those who wanted to know more. ${ }^{17}$

The university can function as a critical place for information about Islam when other sources, such as the media, are unreliable. It can also be a space in which to negotiate Muslim identity in politically difficult times. Azam related a discussion she had with several Muslim students about their responsibilities to educate the wider American public about Islam after the San Bernardino attack in late 20I5. When a few of her students explained that they were tired of apologizing about Islam after Muslim-initiated terrorist attacks, Azam challenged them. "I told them, most of the people who say they are tired actually have not done very much. I do not get tired, and I understand we are living in a complex world where people are afraid of Muslims .... But there are also people who do bad things in the name of Islam." ${ }^{18}$ According to Azam, these students needed to hear that the work of justice, including working for greater understanding among citizens, is a difficult but necessary religious and civic duty.

Chaudhry, Azam, and Ali have engaged in careful analyses in showing how Sunni exegetical and legal traditions are pluralistic and diverse. They also approach their work from a normative angle, which pursues gender justice for Muslim women, but also social justice more broadly. Their work is at once descriptive, focusing on historical texts and various methods of interpretation, and normative, addressing contemporary crises experienced by Muslim communities and individuals. Thus, the binary created in the study of religion between descriptive and normative work simply does not hold for this type of scholarship; it also challenges the idea that insiders to a tradition cannot be critics of it.

A commitment to justice is foundational to this approach to scholarship. In their respective interviews, Azam and Chaudhry each mentioned the importance of reaching observant Muslim women with their scholarship, and in particular, of helping women understand that gender hierarchies are the work of fallible human beings. Ali's revised edition of Sexual Ethics and Islam includes more discussion of contextual factors that perpetuate structural injustice, such as economic disparity, racism, and Western military intervention. Ali described the military and police violence of the present - whether in places like Palestine or on the streets of Baton Rouge - as "more heart-breaking" than the misogyny of scholars who have been dead for a millennium. Although, she noted, "The dehumanization of others and unwillingness to grant full human capacity to people not like oneself is at play in both contexts." ${ }^{\text {I9 }}$ These words are a testament to the moral failure of human beings as well as to the ongoing need for justice.

In conclusion, these scholars have engaged in innovative scholarship that continues to advance discourse in law and religion, Islamic studies, and gender studies. This scholarship does not emerge from a vacuum, and responds to serious political and ethical questions that Muslims and nonMuslims encounter in the contemporary world. As Ali, Chaudhry, and Azam have shown, one way of beginning to address such questions is to better understand how governing assumptions of past traditions and frameworks are appropriated-and often misunderstood-in the present, resulting in contradictions. Sometimes this work exposes deficiencies in contemporary ideas about gender justice, or identifies consistent and recurring ethical problems in human societies, such as the persistent need to create "others." Certainly these insights are applicable to a range of religious and secular legal contexts. It is likely therefore that the work of these three scholars will have a lasting impact on studies of religion, gender, and violence.

I7 Ibid.

I8 Azam, interview.

I9 Ali, interview. 